\title{
PROGRAM PEMBERDAYAAN ANAK KURANG MAMPU PADA PANTI SOSIAL (Studi di UPTD Panti Sosial Anak Dan Remaja Dinas Sosial Provinsi Sulawesi Tenggara)
}

Hanani Firdhotul Jannah, Bahtiar, Sarpin

Jurusan Ilmu Kesejahtraan Sosial, Fakultas Ilmu Sosial Dan Ilmu Politik Universitas Halu Oleo, Kendari

Jl. H. E. A. Mokodopit, Kendari 93232

e-mail:pink47578@gmail.com, bahtiar_unhalu@yahoo.co.id, sarpin_socius@yahoo.co.id

\begin{abstract}
ABSTRAK
Kesejahteraan sosial anak dapat terpenuhi dengan adanya program kesejahteraan anak (PKSA). Salah satu lembaga kesejahteraan sosial anak yang melaksanakan program kesejahteraan sosial anak khususnya menanggulangi masalah anak kurang mampu atau dhua'fa salah satunya adalah Unit Pelaksanaan Teknis Daerah Panti Sosial Anak Dan Remaja yang berada di bawah naungan Dinas Sosial Provinsi Sulawesi Tenggara, yang dalam pelaksanaannya dilapanagn pengasuh panti selalu memberikan yang terbaik bagi anak-anak asuh selaku orang tua pengganti. Penelitian ini bertujuan mengetahui pemberdayaan anak kurang mampu berbasis panti sosial serta keberhasilan yang telah di capai setelah mendapat pemberdayaan. Metode penelitian yang digunakan dalam penelitian ini adalah metode kualitatif, dengan teknik pengumpulan data yang di gunakan adalah teknik wawancara, observasi, dan dokumentasi. Sumber data yang di gunakan adalah sumber data primer dan sekunder. Analisis data dalam penelitian ini dilakukan dengan deskriptif kualitatif dan kemudian di tarik kesimpulan dari data yang diperoleh melalui informan yang relevan dengan penelitian. Hasil dari penelitian ini, pemberdayaan yang pihak panti berikan untuk anak-anak asuh berupa program pendidikan (pembinaan sepritual/kerohanian, bimbingan kemandirian, dan pendidikan) dan program pelatihan (pelatihan keterampilan merias untuk wanita dan menjahit untuk laki-laki dan wanita). Adapun keberhasilan yang telah di capai yaitu mereka dapat menjalankan fungsi sosialnya dalam keluarga dan masyarakat, dapat terbentuknya kemandirian dalam memenuhi kebutuhan hidup, dapat mengembangkan keterampilan yang di peroleh, dan dapat berguna bagi masyarakat.
\end{abstract}

Kata Kunci: Program, Pemberdayaan, Anak Kurang Mampu, Panti Sosial.

\section{PENDAHULUAN}

Anak merupakan generasi penerus bangsa yang harus dididik, diperhatikan dan diberi kasih sayang oleh berbagai pihak, dan diperhatikan akan hak-haknya mulai dari lingkup terkecil. Hal ini dapat dilakukan mulai dari lingkungan keluarga, lingkungan masyarakat, bangsa dan negara. Sejak lahir anak diperkenalkan dengan pranata, aturan, norma dan nilai-nilai budaya yang berlaku 


\section{WELVAART}

JURNAL ILMU KESEJAHTERAAN SOSIAL

Jurusan Ilmu Kesejahteraan Sosial Fakultas Ilmu Sosial dan Ilmu Politik Universitas Halu Oleo

melalui pembinaan yang diberikan oleh orang tua dalam keluarga. Di sini pembinaan anak sebagai bagian dari proses sosialisasi yang paling penting dan mendasar karena fungsi utama pembinaan anak adalah mempersiapkan anak menjadi warga masyarakat yang mandiri. Kondisi masa sekarang akan menentukan masa depan anak. Mulai dari kebutuhan fisik, sosial maupun mental harus terpenuhi agar tumbuh generasi yang berkualitas. Berdasarkan UndangUndang RI No. 35 Tahun 2014 tentang perubahan atas Undang-Undang No 23 Tahun 2002 tentang perlindungan anak bahwa Negara Kesatuan Republik Indonesia (NKRI) menjamin kesejahteraan tiap warga negaranya termasuk perlindungan terhadap anak yang merupakn hak asasi manusia.

Perkembangan anak sangat didukung oleh tempat atau lingkungan ia berada. Keluarga merupakan wadah yang paling baik, dimana orang tua akan memberikan kasih sayang, pendidikan yang layak serta memenuhi kebutuhan sehari-hari. Dalam kenyataannya di kehidupan sosial, tidak semua orang tua mempunyai kesanggupan dan kemampuan penuh untuk memenuhi kebutuhan pokok anaknya dalam rangka mewujudkan kesejahteraan anak.

Perkembangan pendidikan generasi muda sebagai penerus kepemimpinan Bangsa Indonesia, nampaknya belum menunjukkan hasil yang signifikan. Krisis multidimensi yang masih melanda negara ini, harus diakui masih menyisihkan banyak persoalan, diantaranya disebabkan oleh faktor kemiskinan baik miskin harta (ekonomi), miskin ilmu, miskin iman dan sebagainya (Abdul Wahid dalam Patinegara, 2010:24). Sehingga menjadikan banyak anak putus sekolah dan bekerja di sektor publik yang berbahaya. Dalam dunia pendidikan, Tim Nasional Percepatan Penanggulangan Kemiskinan (TNP2K) mendata, masih ada sebanyak 4,1 juta anak usia sekolah di Indonesia, namun tidak mengenyam bangku sekolah (http://nasional.kompas.com). Hal ini tidak sesuai dalam sistem pendidikan Nasional di Indonesia, bahwa pendidikan Nasional berdasarkan pancasila dan UU No. 20 Tahun 2003 tentang sistem pendidikan Nasional. Pendidikan Nasional berfungsi mengembangkan kemampuan dan membentuk watak serta peradaban bangsa yang bermartabat dalam rangka mencerdaskan kehidupan bangsa, bertujuan untuk berkembangnya potensi peserta didik agar menjadi manusia yang 


\section{WELVAART}

\section{JURNAL ILMU KESEJAHTERAAN SOSIAL}

Jurusan Ilmu Kesejahteraan Sosial Fakultas Ilmu Sosial dan Ilmu Politik Universitas Halu Oleo

beriman dan bertaqwa kepada Tuhan Yang Maha Esa, berakhlak mulia, sehat, berilmu, cakap, kreatif, mandiri, dan menjadi warga negara yang demokratis serta bertanggung jawab (http://kelembagaan.ristekdikti.go.id).

Mendidik seorang anak hingga tumbuh menjadi anak yang baik adalah tanggung jawab setiap orang tua. Hal ini, terjadi apabila anak tinggal bersama orang tuanya. Pada kenyataanya, anak di Indonesia masih banyak yang tidak hidup bersama orang tuanya, bahkan menjadi anak terlantar. Belum lagi kemiskinan yang membuat mereka harus menghentikan langkah dalam dunia pendidikannya, baik karena ketidak mampuan keluarga maupun faktor lain yang memaksa anak untuk tidak sekolah. Dalam Amandemen UUD 1945 pasal 31 ayat (1) menyatakan bahwa setiap warga Negara berhak mendapatkan pendidikan, ayat (2) menjelaskan setiap warga Negara wajib mengikuti pendidikan dasar dan pemerintah wajib membiayainya. Secara ideologis dinyatakan bahwa fakir miskin dan anak-anak terlantar dipelihara oleh negara (UUD 1945 Pasal 34). Hal ini tentunya mengimplikasikan pada usaha kemanusiaan terhadap anak-anak yang terlahir dalam kondisi memprihatinkan agar mendapat perawatan dan pemeliharaan yang mencukupi dalam semua aspek kehidupannya dengan mengembangkan sistem jaminan sosial bagi seluruh rakyat dan memberdayakan masyarakat lemah dan tidak mampu sesuai dengan martabat dan kemanusiaan.

Pemerintah juga bertanggung jawab atas penyediaan fasilitas pelayanan kesehatan dan pelayanan umum yang layak. Anak berhak mendapatkan kesejahteraan, asuhan, dan bimbingan berdasarkan kasih sayang baik dalam keluarganya maupun di dalam asuhan khusus untuk tumbuh dan berkembang dengan wajar. Tentu saja hal ini menjadi tanggung jawab dan tugas dari penyelenggara negara yakni pemerintah. Karena anak-anak yatim piatu maupun anak telantar dan anak-anak kurang mampu sebagai salah satu permasalahan sosial anak, membutuhkan orang-orang atau lembaga (panti atau yayasan) yang mapan sebagai tempat untuk berlindung dan berkembang menjadi anak-anak yang di kemudian hari akan memimpin negara.

Melalui Kementrian Sosial dan Dinas Sosial sebagai Unit Pelaksanaan Teknis di Daerah (UPTD), maka untuk dilaksanakan pemberdayaan ditiap-tiap 


\section{WELVAART}

\section{JURNAL ILMU KESEJAHTERAAN SOSIAL}

UPTD berbasis panti sebagai wujud perhatian pemerintah kepada warga negara khususnya anak. Fungsi panti menjadi penting untuk meminimalisir kondisi anakanak yang tidak mampu dalam melanjutkan pendidikan. Panti asuhan yang menampung sekaligus membiayai pendidikan bagi anak-anak tersebut, umumnya dari keluarga miskin dan tidak mampu yang merupakan alternatif pilihan yang diambil oleh anak agar dapat menjalani kehidupan yang lebih baik serta memberikan jalan keluar dari masalah yang dialami.

Dari pengajaran di panti asuhan diharapkan akan diperoleh pengetahuan, keterampilan, pendidikan serta perilaku yang baik. Keterampilan ini akan dipergunakan untuk membantu dirinya sendiri serta dapat membantu orang lain yang membutuhkan. Hal ini bersinggungan dengan Undang-Undang, yaitu UU No.23 tahun 2002 tentang Perlindungan Anak (PA) pasal 1 ayat 10 UU PA yang isinya adalah, "Anak asuh adalah anak yang diasuh oleh seseorang atau lembaga, untuk diberikan bimbingan, pemeliharaan, perawatan, pendidikan, dan kesehatan, karena orang tuanya atau salah satu orang tuanya tidak mampu menjamin tumbuh kembang anak secara wajar". Dengan melaksanakan pelayanan sosial berbasis panti, diharapkan anak-anak yang menjadi anak asuh di panti tersebut dapat terpenuhi kebutuhan dasarnya.

Sebagai UPTD satu-satunya di tingkat Provinsi, yaitu UPTD Panti Sosial Anak dan Remaja Dinas Sosial Provinsi Sulawesi Tenggara yang menyelenggarakan kesejahteraan sosial berbasis panti, serta merupakan lembaga pelayanan kesejahteraan sosial yang memiliki tugas dan fungsi untuk melakukan pendapingan terhadap keluarga dan masyarakat dalam pengasuhan anak, Depatermen Sosial RI, 2008:11, (http://bulelengkab.go.id). Dari observasi awal penulis menemukan bahwa UPTD Panti Sosial Anak dan Remaja Dinas Sosial Provinsi Sulawesi Tenggara ini, bergerak di bidang anak terutama anak-anak yang kurang mampu dan remaja dengan menggunakan sistem rekrutmen, dan anakanak yang tinggal di panti umummya (90\%) masih memiliki kedua orang tua dan dikirim ke panti dengan alasan utama untuk melanjutkan pendidikan. Untuk anak sebagai mana dalam UU No. 35 Tahun 2014 tentang perubahan UU No. 23 Tahun 2002 tentang perlindungan anak, bahwa yang di maksud dengan anak adalah 
mereka yang berusia 0-18 tahun. Akan tetapi anak-anak yang masuk di panti asuhan tersebut hanya diperbolehkan bagi mereka yang berumur 10-18 Tahun, terutama mereka yang putus sekolah mulai dari kelas 4 SD-SMA. Pada temuan kedua bahwa Unit Pelayanan Teknis Daerah (UPTD) Panti Sosial Anak dan Remaja (PSAR) Dinas Sosial Provinsi Sulawesi Tenggara kini membina 50 orang anak kurang mampu atau bermasalah dari berbagai latar belakang keluarga dan lingkungan. Mereka berasal dari berbagi kabupaten dan kota di seluruh wilayah Sulawesi Tenggara seperti Kabupaten Konawe, Konsel, Kolaka, Buton, Muna, Kota Kendari, dan Kota Bau-Bau. Pada masing-masing anak akan di seleksi berdasarkan rekomendasi dari berbagai pihak terkait kedudukan dan status anak tersebut yang akan dibina selama di Panti Sosial Anak dan Remaja berdasarkan daerah asal. Dari hasil seleksi tersebut mereka akan langsung dijemput oleh pihak panti untuk diasramkan di UPTD Panti Sosial Anak dan Remaja.

UPTD Panti Sosial Anak dan Remaja juga memprogramkan berbagai kegiatan anak dalam rangaka memberdayaakan anak seperti dapat terwujudnya perlindungan, pelayanan sosial dan kemandirian anak dengan cara meningkatkan iman dan taqwa, pemenuhan kebutuhan dasar dan hak Anak untuk kepentingan terbaik tanpa asuhan or ang tua, melakukan pencegahan dan upaya perlindungan sosial anak serta meningkatkan kualitas dan kuantitas, Sarana dan Prasarana Pelayanan Kesejahteraan Sosial Anak.

Berdasarkan latar belakang di atas, maka penulis tertarik untuk melakukan penelitian yang berjudul "Program Pemberdayaan Anak Kurang Mampu Pada Panti Sosial (Studi di UPTD Panti Sosial Anak dan Remaja Dinas Sosial Provinsi Sulawesi Tenggara)".

\section{METODE PENELITIAN}

Metode penelitian yang digunakan adalah metode deskriptif kualitatif. yaitu suatu metode yang digunakan untuk mengambarkan atau menganalisis suatau hasil penelitian. Menurut (Upe 2016:45) "Penelitian Kualitatif adalah peneliti memandang realita semata sebagai objek yang berada diluar, bebas dari penelitiannya, dan dapat diukur secara objektif dengan menggunakan instrument kuesioner. 


\section{PEMBAHASAN}

Program pemberdayaan yang panti berikan terhadap anak-anak asuh yaitu berupa

\section{Program Pendidikan}

a. Program pembinaan sepritual/kerohanian

UPTD-PSAR memberikan pelayanan sosial berupa pendidikan non forma yang lebih mengarah kepada keagamaan seperti pembinaan spritual/kerohanian untuk anak-anak asuh yang berada di panti . Hal ini sesuai yang di ungkapkan oleh kepala UPTD-PSAR.

"Selain pendidikan formal UPTD-PSAR juga memberikan pendidikan non formal seperti kegiatan belajar mengaji yang mereka terima di panti agar anak-anak tetap dapat memahami dan menjalankan kewajibanya sebagai seorang muslim sejak dini”. (Bapak Syahruddin, Jum'at 30 Agustus 2019).

Pendidikan non formal menurut Undang-Undang RI. No. 20 Tahun 2003 tentang Sistem Pendidikan Nasional Pasal 26 ayat 1 menyebutkan bahwa: ” pendidikan non formal diselenggarakan bagi warga masyarakat yang memelurkan layanan pendidikan yang berfungsi sebagai penganti, penambah, dan pelengkap pendidikan formal dalam rangka mendukung pendidikan sepanjang hayat”. Dari pembahasan yang telah dijelaskan dapat disimpulkan bahwa UPTD Panti Sosial Anak dan Remaja memberikan pelayanan sosial berupa pendidikan non formal untuk anak-anak asuh yang berada di panti. sebagai mana visi dan misi yang ada di UPTD-PSAR bahwa agar dapat terwujudnya perlindungan dan pelayanan sosial anak tanpa pengasuhan orang tua dan terbentuknya iman dan taqwa anak dengan pendidikan non formal (pembinaan sepritual/ kerohanian). Hal ini sesuai ungkapan salah satau anak asuh yang ada di panti.

"Selain kita belajar disekolah pelajaran umum, kita juga belajar mengaji, belajar mengajinya kak setiap ba'da magrib di mushola panti yang di bina oleh Bapak Nasdar". (Yeni, Jum'at 23 Agustus 2019).

Dengan adanya pendidikan non formal tersebut anak-anak dapat lebih mengerti akan pentingnya pendidikan agama, dan lebih memiliki sifat yang religius, serta memiliki kepribadian yang baik. Hal inilah yang peneliti dapatkan dari hasil observasi atau pengamatan yang peneliti lakukan bahwasannya anakanak asuh dipanti pada setiap habis magrib mereka mengaji di mushola yang di 
pimpin oleh bapak Nasdar selaku guru mengaji sekaligus pembina anak-anak di asrama, serta seperi yang peneliti lihat bahwa anak-anak asuh di panti mereka rata-rata pandai mengaji atau melantunkan ayat suci al-qur'an dengan baik. Mereka juga sangat semangat dalam belajar mengaji terbukti dengan rutinnya mereka berada di mushola saat solat magrib tiba.

\section{b. Bimbingan Kemandirian}

Anak-anak yang berada di panti diajarkan cara menjaga lingkungan tempat tinggal dan tempat tidur, kamar mandi, ruang tamu, ruang tengah, maupun di sekitar pekarangan tempat tinggalnya (asrama), serta saling membantu jika ada salah satu teman yang tinggal satu asrama sedang sakit agar anak tidak mudah bergantung dengan orang lain. Seperti halnya dalam hasil wawancara kepada Pembina disalah astu asrama atau wisma bahwa:

"setiap anak-anak kami ajarkan kemandirian dengan setiap minggu di periksa setiap tempat tidur, kamar mandi sampai lingkungan tempat tinngal sekitar serta diberikan arahkan dan motovasi tentang wajibnya menjaga kebersihan lingkungan sekitar dan saling membantu sesama penghuni asrama untuk melapor dan menjaga jika ada salah satu temannya sakit" (Bapak Yanto, 26 Agustus 2019).

Dari wawancara di atas bahwasannya pembina selalu mengajarkan bahkan mengingatkan anak-anak untuk mandiri dengan mengajarkan anak-anak dalam membersihkan tempat tidurnya maupun lingkungan tempat tinggalnya. Peneliti juga melihat bahwasanya pembina panti pun ikut serta dalam melakukan pembersihan lingkungan panti setiap hari jum'at pagi atau sore serta pada hari libur dengan memotong rumput yang ada di sekeliling lingkungan panti. Dari sisnilah sudah dapat dilihat bahwa selain pihak panti mengajarkan kepada anakanak akan kemandirian mereka juga mempraktekkan secara langsung dalam menjaga kebersihan lingkungan panti.

Hal ini dapat dilihat bahwa kemandirian atau mandiri adalah sikap yang mampu mengurus kehidupannya sendiri dan tidak menjadi beban orang lain, Sikap mandiri bukan sikap egois atau hidup sendiri, malainkan sikap bersedia dan mampu membangun kehidupan sendiri dalam rangka kebersamaan, (Sa'diyah 34:2017). 


\section{WELVAART}

\section{JURNAL ILMU KESEJAHTERAAN SOSIAL}

Selanjutnya program pendidikan di mana UPTD Panti Sosial Anak dan Remaja memberikan pelayanan sosial dalam mendukung pemberdayaan anak yaitu berupa pendidikan untuk anak-anak asuh yang berasal dari keluarga yang kurang mampu, anak-anak yatim piatu, terlantar, broken home, dan anak-anak yang tetap ingin melanjutkan sekolah hingga tamat. Hal ini sesuai yang di ungkapkan oleh kepala UPTD-PSAR.

"Bentuk pendidikan yang disediakan oleh panti untuk anak-anak yaitu pendidikan dari sekolah dengan bekerja sama dengan pihak sekolah.". (Bapak Syahruddin, Jum'at 30 Agustus 2019).

Dari wawancara di atas bahwa panti menyediakan pemberdayaan pendidikan formal untuk anak-anak asuh meskipun pendidikan formal tersebut berda di luar lingkungan panti, tetapi tidak menjadi penghalang bagi panti untuk tetap memberdayakan anak-anak melalui pendidikan. Seperti halnya bahwa pendidikan adalah hal yang sangat penting bagi usia anak-anak seperti kata $\mathrm{Ki}$ Hajar Dewantara dalam mengartikan pendidikan bahwa sebagai daya upaya untuk memajukan budi pekerti, pikiran serta jasmani anak, agar dapat memajukan kesempurnaan hidup yaitu hidup dan menghidupkan anak yang selaras dengan alam dan masyarakat, (Nurkholis 26:2013). Hal inilah yang peneliti temui di lapangan bahwa anak-anak tetap semangat untuk sekolah meski tempat sekolah mereka jauh dari panti. Hal ini juga yang di ungkapkan oleh bagin Pelayanan anak bahwa:

"Anak-anak di sini kami sekolahkan, kami berkerja sama dengan sekolahsekolah di luar panti untuk menerima anak-anak asuh dari panti untuk dididik”. (Bapak Kulle, Jum'at 30 Agustus 2019).

Dari wawancara diatas bahwasanya pemberdayaan pendidikan yang pihak panti berikan kepada anak asuh yaitu dengan mensekolahkannya meskipun sekolahnya berada diluar area panti. Mereka juga diberikan uang transportasi, sehingga walaupun anak-anak kesekolah tidak akan kesulitan dengan biaya transportasi. Sesuai dengan yang peneliti dapatkan di lapangan bahwa anak-anak terlihat seperti sudah tidak ada beban yang mereka tanggungg karna mereka terpenuhi segala kebutuhannya terutama transportasi yang kemungkinan membuat mereka merasa terbebani karna tidak adanya uang yang mereka miliki untuk transportasi ke sekolahnya. 


\section{WELVAART}

\section{JURNAL ILMU KESEJAHTERAAN SOSIAL}

Jurusan Ilmu Kesejahteraan Sosial

2. Program Pemberdayaan Pelatihan Keterampilan

Selain program pemberdayaan non fisik UPTD Panti Sosial Anak dan Remaja juga memiliki program pemberdayaan fisik yaitu berupa:

a. Program pelatihan keterampilan merias

Adapaun program pelatihan keterampilan ini yaitu anak-anak yang berada di panti mereka menyalurkan keterampilannya sesuai dengan bakat yang mereka miliki atau pun minatnya. Hal ini sesuai dengan ungkapkan bagian vokasional dan advokasi.

“anak-anak disini juga diberikan pelatihan keterampilan seperti tatarias yang sesuai bakatnya atau minatnya guna membuat anak dapat memiliki keterampina untuk bekal mereka setelah selesai dari panti dan mereka dapat memperdayakan dirinya sendiri maupun orang lain, meskipun sekarang bagian tata rias hanya di peruntukkan bagi para wanita, karna dulu tata rias bisa di ikuti oleh laki-laki juga. ". (Ibu Hj. Asmawati, S.Sos 3 September 2019).

Dari hasil wawancara di atas bahwa anak-anak di panti juga diberi pelatihan keterampilan agar mereka dapat memberdayakan dirinya sendiri maupun orang lain dengan menyalurkan bakatnya atau skill yang telah diperolehnya atau dimiliki dan dapat membantu oarng lain untuk mendapatkan suatu pekerjaan agar dapat tercukupinya kebutuhan hidupnya. Hal ini juga sesuai dengan ungkapan kepala UPTD-PSAR.

“Anak-anak di sini kami berikan pelatihan-pelatihan yang nantinya akan membuat anak-anak menjadi mandiri dan mereka dapat memberdayaakan dirinya dengan keterampilan yang sudah diberikan". (Bapak Syahruddin, Selasa 3 September 2019).

Dari hasil wawancara di atas bahwa pihak panti sangat antusias dalam memberikan pemberdayaan berupa pelatihan guna membuat anak-anak menjadi mandiri dan dapat memberdayakan dirinya. Sesuai dengan observasi atau pengamatan yang peneliti dapatkan bahwa di UPTD panti sosial anak dan remaja terdapat gedung khusus pelatihan keterampilan yang pihak panti sediakan khusus untuk anak-anak yang belajar atau menyalurkan keterampilannya.

b. Program pelatihan menjahit

Selain keterampilan merias UPTD Panti Sosial Anak dan Remaj juga memberi pelatihan menjahit. Hal ini sesuai yang diungkapkan oleh Pekerja sosial sekaligus pendamping anak-anak. 
"selain keterampilan merias panti juga menyediakan pelatihan keterampilan menjahit agar mereka dapat memilih di mana bakat mereka dapat disalurkan". (Ibu Ratniati, 3 September 2019).

Hasil dari wawancara di atas bahwa pelatihan yang panti berikan selain pelatihan merias juga diberikan pelatihan menjahit, agar anak-anak dapat lebih leluasa untuk memilih keterampilan yang sesuai dengan bakat yang mereka minati. Mereka juga dapat saling tukar pengalaman keterampilannya dengan teman-teman lainnya sehingga saat mereka selesai dari panti mereka sudah tidak kesulitan untuk mencari pekerjaan karna mereka sudah memiliki bekal keterampilan yang mereka dapat di panti sehingga mereka dapat mencukupi kebutuhan hidunya serta dapat membantu masyarakat yang membutuhkannya.

Adapun manfaat dari program pemberdayaan anak kurang mampu setelah mendapatkan pemberdayaan yaitu

1. Dapat Menjalankan Fungsi Sosialnya Didalam Keluarga dan Didalam Kehidupan Bermasyarakat.

Di sini bahwa alumni atau anak-anak asuh yang dulunya di asuh di UPTD Panti Sosial Anak dan Remaja dapat menyelesaikan sekolahnya yang dulunya kemungkinan besar mereaka tidak dapat melanjutkan sekolahnya karna faktor ekonomi maupun faktor lainnya yang membuat anak putus sekolah. Sehingga mereka dapat menyelesaikannya dengan pemberdayaan berupa pendidikan yang pihak panti berikan. Hal ini sesuai dengan ungkapan Pekerja sosial sekaligus pembina anak-anak panti.

"anak-anak yang sudah selesai pendidikannya dan kami kembalikan kepada orang tuanya kini mereka sebagian dapat melanjutkan pendidikan kejenjang perguruan tinggi dan juga sebagian mereka sudah memiliki pekerjaan contohnya dari mereka ada yang sudah menjadi polisi, pengawai, pedagang dll”. (Ibu Ratniati, Senin 2 September 2019).

Dilihat dari wawancara di atas bahwa alumni dari anak-anak yang panti berdayakan mereka dapat meperdayaan dirinya sendiri maupun orang lain dengan pemberdayaan yang pihak panti berikan. Hal ini sesuai dengan yang peneliti dapatkan di lapangan bahwa ada salah satu alumni dari anak panti sudah dapat memberdayakan dirinya sendiri serta dapat memberdayakan orang lain dengan menjadi pembina bagi anak-anak yang ada di panti sekaligus sebagai guru mengaji. 
2. Dapat terbentuknya kemandirian dalam memenuhi kebutuhan hidup.

Hasil yang diterima oleh alumni atau anak asuh dari pemberdayaan yang pihak panti berikan membuat anak asuh dapat lebih mandiri dan dapat memenuhi kebutuhan hidupnya. Karena kebutuhan hidup manusia adalah sesuatu yang diperlukan manusia untuk mempertahankan memperlangsungkan kehidupan. Hal ini sesuai dengan ungkapan Pekerja sosial sekaligus pembina anak-anak panti.

"Semua anak-anak alumni dari panti ini kini mereka sudah dapat mandiri dan dapat kembali keberfungsian sosialnya yang dulu pernah hilang akibat putus sekolah karna ekonomi orang tua yang tidak mampu, mereka yang kehilangan salah satu orang tuanya, bahkan anak broken home Alhamdulillah kini mereka dapat bermanfaat di tegah masyarakat maupun bagi dirinya sendiri”. (Ibu Ratniati, Senin 2 September 2019).

Dari wawancara di atas bahwa alumni dari anak-anak asuh yang berada di panti kini mereka dapat mandiri dan dapat bermanfaat di tengah masyarakat maupun dirinya sendiri. Seperti halnya yang peneliti dapatkan di lapangan yaitu bapak Nasdar bahwa beliau dulunya menjadi anak panti kini beliau dapat bermanfaat di tengah masyarakat dengan mendidik kembali anak-anak yang kurang beruntung menjadi anak-anak yang dapat memberdayakan dirinya, serta beliau juga menjadi penyemangat anak-anak asuh yang berada dip anti untuk tetap semangat dalam belajar. Hal ini dapat dilihat dari hasil wawancara dari salah satu alumni panti yang saat ini sudah berhasil.

"Setelah saya lulus dari panti Alhamdulillah saya dapat mandiri dan kembalinya keberfungsian sosial saya dari sikap trauma karana ejekan dari teman-teman karna saya sempat putus sekolah, dan Alhamdulillah saya dapat melanjutkan sekolah saya sampai lulus SMA dan mendapat pekerjaan seperti sekarang ini. Alhamdulillah juga dari saya menjadi anak panti dulunya kini saya dapat menjadi Pembina anak panti”. (Bapak Nasdar, Rabu 4 September 2019).

Dari hasil wawancara diatas bahwa pemberdayaan yang pihak panti berikan sangat bermanfaat bagi anak-anak asuh serta membuat anak-anak dapat kembali keberfungsian sosialnya terutama mereka dapat mandiri serta dapat memenuhi kebutuhan hidupnya sendiri dengan pekerjaan yang mereka miliki saat ini.

3. Dapat mengembangkan keterampilan yang diperolehnya 


\section{WELVAART}

\section{JURNAL ILMU KESEJAHTERAAN SOSIAL}

Pemberdayaan keterampilan yang pihak panti berikan juga sangat bermanfaat bagi anak-anak asuh karena panti dapat membina dengan mengembangkan keterampilan yang anak-anak miliki sehingga mereka dapat mengembangkan keterampilannya setelah mereka keluar dari panti. Mereka juga dapat mengajarkan keterampilan mereka kepada masyarakat yang ada di sekitar tempat tinggalnya masing-amsing dengan menbuka usaha dari keterampilan yang mereka miliki. Terbukti dari usaha yang alumni anak panti yang sudah mengembangkan keterampilannya. Hal ini sesuai dengan hasil wawancara dari kepala UPTD-PSAR.

"Adapun keberhasilan yang dapat pihak panti capai maupun anak-anak yaitu untuk panti sendiri apa bila anak-anak yang sudah kami pulangkan kepada orang tuanya masing-masing mereka dapat memenuhi kebutuhan hidunya dengan keterampilan yang sudah mereka peroleh kami sangat bangga karna kami berhasil memberdayakannya, serta utuk anak-anak itu sendiri manfaat keterampilan bahwa memudah untuk mendapat pekerjaan". (Bapak Syahruddin, Rabu 4 September 2019).

Dari wawancara di atas pihak panti meresa sangat senag dan bangga apabila alumi dari anak-anak asuhnya dapat menjalankan keterampilan yang di perolehnya serta membuat mereka dapat memiliki penghasilan yang mejadi faktor pendukung dalam pemenuhan kebutuhan hidupnya. Seperti uangkapan halnya yang peneliti dapatkan dari uangkapn salah seorang pegawai panti yang merasa cukup senang karena para alumni dapat memudahkan kehidupannya dengan bekal keterampilan yang sudah diberikan.

4. Masyarakat dapat menggunakan/menerimanya sebagai mana mestinya.

Keberdayaan Anak Kurang Mampu Setelah Mendapatkan Pemberdayaan selanjutnya yaitu bahwa mereka dapat berguna dalam masyarakat dan juga masyarakat dapat menerimanya sebagai mana mestinya seorang penduduk yang bertempat tinggal di lingkungan yang memiliki beranekaragam suku (hidup bertetangga). Hal ini sesuai dengan ungkapan Pekerja sosial sekaligus Pembina anak-anak.

"Alhamdulillah anak-anak yang sudah tamat dari sini kini mereka dapat di terima kembali oleh masyarakat sekitar tempat tinggalnya maupun masyarakat lainnya, karena sebagian dari alumni disini ada yang sudah menjadi seorang polisi yang dapat menjadi pelindung bagi masyarakat, dan kami sangat bangga". (Ibu Ratniati, Rabu 4 September 2019). 
Dari wawancara di atas bahwa para alumni kini mereka dapat berguna bagi masyarakat dan dapat di terima sebagai mana mestinya dikalangan masyarakat pada umunya. Mereka juga bahkan ada yang menjadi pelindung masyarakat. Seperti halnya yang peneliti dapatkan dari uangkapan salah satu pegawai panti yang menceritakan kesuksesan yang ada para alumni panti dyang dari mereka ada yang menjadi pedagang sukses.

\section{E. KESIMPULAN}

Program pemberdayaan anak kurang mampu yang UPTD Panti Sosial Anak dan Remaja Berikan yaitu berupa program pendidikan yang meliputi pembinaan sepritual/kerohanian, pelatihan keterampilan, pendidikan. Selain program pendidikan panti juga memberikan program pelatihan keterampilan merias dan menjahit. Adapun manfaat yang dari program pemberdayaan yang pihak panti berikan terhadap anak asuh yaitu bahwa mereka Dapat Menjalankan Fungsi Sosialnya Didalam Keluarga dan Didalam Kehidupan Bermasyarakat, Dapat terbentuknya kemandirian dalam memenuhi kebutuhan hidup, dapat mengembangkan keterampilan yang diperolehnya dan masyarakat dapat menggunakan/menerimanya sebagai mana mestinya.

\section{F. DAFTAR PUSTAKA}

Adi, Rukminto Isbandi. 2015, Kesejahteraan sosial :(Pekerjaan sosial, Pembangunan Sosial, dan Kajian Pembangunan). Jakarta : PT Raja Grafindo Persada.

Almareza, Setiawan 2016. Perencanaan Pelatihan Keterampilan Kecakapn Hidup Di Desa Vokasi Candi Kecamatan Bandung Kabupaten Semarang. Kripsi Jurusan Pendidikan Non Formal Fakultas Ilmu Pendidikan Universitas Negeri Semarang.

Nurkholis, 2013. Pendidikan Dalam Upaya Memajukan Teknologi. Vol. 1 No. 1, hal 26.

Pandoyo, Bismo 2010. Tingkat Pemenuhan Kebutuhan Hidup Para Anak Asuh Panti Asuhan Pangrekso Dalem Temanggung. Skripsi Jurusan Ilmu Pendidikan Program Studi Bimbingan dan Konseling Fakultas Keguruan Ilmu Pendidikan Universitas Sanata Dharma Yogyakarta.

Patinegara, sunarjo 2010. Pemberdayaan Pendidikan Bagi Anak-Anak Kurang Mampu Oleh Panti Asuhan Yatim Putra Muhammadiyah Yogyakarta. Skripsi Jurusan Pendidikan Isalam FakultasTarbiyah Universitas Islam Negeri Sunan Kalijaga Yogyakarta.

Muzakki, Ahmad Naufal 2015. Bakat Dan Minat. Skripsi Jurusan Pendidikan Biologi Fakultas Pendidikan Matematika Dan Ilmu Pengetahuan Alam Universitas Pendidikan Indonesia. 
Sa'diyah, Rika 2017. Pentingnya Melatih Kemandirian Anak. Vol. XVI No. 1, hal 34. (http://nasional.kompas.com/. Data (TNP2K) Anak Putus Sekolah Di Indonesia. penulis Ade Sulaeman Tahun 2017, di akses pada tanggal 11 Juli 2019 jam 20.00 wita).

Upe Ambo 2016. Metode Penelitian Sosial (Filosofi) dan Desai Praktis). Kendari Literacy Institute.

(http://kelembagaan.risetdikti.go.id <PDF hasil web Undang-Undang No 20 Tahun 2003 Tentang Sistem Pendidikan Nasional. Diakses pada tanggal 21 juli jam 10.30 wib).

(http://bulelengkab.go.id/detail/artikel/lembaga-kesejahteraan-sosial-anak-Iksa-93. Program Kesejahteraan Sosial Anak. Penerbit Kemensos Ri Tahun 2014 diakses tanggal 23 juli jam 20.00). 